\title{
IAMJ
}

INTERNATIONAL AYURVEDIC MEDICAL JOURNAL

\section{A COMPARATIVE PHARMACEUTICO-ANALYTICAL STUDY OF KASISA BHASMA PREPARED BY TWO METHODS W.S.R. TO MARANA DRAVYAS}

\author{
Nirmala Kushwaha ${ }^{1}$, Urmila Waxar ${ }^{2}$ \\ ${ }^{1,2}$ Assistant Professor, Department of Rasa Shastra and Bhaishajya Kaplana \\ Govt. Dhanvantari Ayurveda College, Ujjain, Madhya Pradesh, India
}

Corresponding Author: kusnirmala@gmail.com

https://doi.org/10.46607/iamj0408112020

(Published online: November 2020)

Open Access

(C) International Ayurvedic Medical Journal, India 2020

Article Received: 15/10/2020 - Peer Reviewed: 08/11/2020 - Accepted for Publication: 15/11/2020

Check for updates

\begin{abstract}
Marana is a very important process which plays most significant role in converting the minerals and metals in to assimilable, efficacious dosage forms, with least or no harmful effects. It is scientific process which includes Shodhana [Purification], Marana [Impregnation followed by calcination] and Amritikarana [removal of residual blemishes] etc. Role of Marana Dravya stands very important in this process as these drugs help in converting the minerals or metals into micro-fine state as well as develop new desirable effects/ properties in the resultant products. Kasisa Bhasma is a popular Bhasma which is prepared from Kasisa [Green Vitriol-chemical formula -FeSo4.7H2O] It is Amla, Tikta, Kashaya in Rasa, Ushna Veerya drug with Vatashleshmahara, Grahi, Netrya, Keshya, Kanduhar, Vishhara, Krimihara, Switrahara, Vranahara properties and is indicated in various disorders i.e. Pandu, Mutrakriccha, Pleeharoga, Krimi, Shwitra, Rajoroddha etc. On analysis of its indications it can be seen that this Bhasma is indicated for internal as well as external use. That's why this formulation for internal as well as external use having Kasisa Bhasma as an ingredient. Literary survey of classics shows various methods of Kasisa Bhasma preparation in which different Marana Dravyas are indicated among these Marana with Snuhipatra Swarasa seems specific which is referred by the text Rasa Tarangini- reference 21/255-258. But AFI referred Rasamritam for Kasisa Bhasma preparation. So the study was planned to compare the Kasisa Bhasma prepared by two methods [AFI vs R.T.] pharmaceutically with special reference to their Marana Dravya used, and analytically on the defined classical and modern parameters of Bhasma Pariksha i.e. Sparsha, Varna, Niramlatva, Rekhapurnatva, loss on
\end{abstract}


drying, ash value, acid insoluble ash, assay for iron etc. to find out the effect of Bhavana Dravya used on the organoleptic and physicochemical characters of Kasisa Bhasma.

Keywords: Kasisa, Marana, AFI, Nimbu Swarasa, Snuhipatra Swarasa, Iron \%.

\section{INTRODUCTION}

Rasakalpa stands superior to any other Aushadh Kalpas as they provide tremendous results even in low dose, are more palatable, fast acting and having miraculous results on the critical disease conditions. Rasa Kalpa has shown a miraculous effect where the other remedies fails. The concept of Marana which includes Bhavana [impregnation in any liquid], Puta [quantum of heat given, incineration], number of Puta etc. plays very important role in converting a raw mineral or metal in to micro fine, assimilable, safer compound with medicinal properties and least or no harmful effects. Besides natural properties new desirable properties are also included through various Marana Dravyas. Kasisa Bhasma is a popular Bhasma which is prepared from Kasisa (green vitriol) and is indicated for various disease i.e. Pandu, Pleeharoga, Krimi, Mutrakrichha, Rajorodha. It is used as an ingredient of various formulations. Classics show several methods of preparation for Kasisa Bhasma. About 15 text provided Kasisa Bhasma process among these Nimbu Swaras is widely used Marana Dravya. Among the other Dravya's Snuhipatra Swaras was specific. As Marana Dravya is very important in preparing a good and defined quality Bhasma, so this study was planned to study two samples of Kasisa Bhasma, $1^{\text {st }}$ prepared by the reference of AFI using Nimbu Swarasas Marana Dravya and 2nd prepared by the reference of Rastarangini using Snuhipatra Swarasa, pharmaceutically and analytically. The two Bhasma sample were tested for different criteria and total iron content and compared to establish the role of Marana Dravya with reference to quality of Kasisa Bhasma.

\section{Aim and Objective:}

1. To prepare two pharmaceutically different sample of Kasisa Bhasma. Sample 1- Rasamritam 3/160 \& AFI, Sample 2 - Rasatarangini 21/255-258

2. To analyse the two prepared Kasisa Bhasma samples on different parameters and compare the result.

Material and Method: Collection of raw materials, Kasisa (Green Vitriol- FeSO4.7H2O), Bhringraj (Eclipta alba), Nimbu Swarasa (Citrus lemon), Snuhipatra Swarasa (Euphorbia nerifolia), Material and equipment's for Puta- Upala, Sharav, Kharal

Pharmaceutical Study: Classic shows that Ayurvedic formulations were never prepared for commercial purpose. There was no separate entity which could be called as drug manufacturer or trader. Changes in formulations were introduced by the physician himself for the benefit of a specific patient. So, one must understand the significance of procedure followed or indicated in different text. Keeping this in mind two references for Kasisa Bhasma preparation are followed here to compare the resultant pharmaceutically and analytically.

The pharmaceutical process was divided into following steps.

$>$ Preparation of Bhringaraja Swarasa

$>$ Kasisa Shodhana by Rasamritam- 3/158

> Preparation of Nimbu Swarasa

$>$ Preparation of SnuhiPatra Swarasa

$>$ Marana of Kasisa by two methods -

1) Rasamritam $3 / 160$ (Recommended by AFI)

2) Rasatarangini $21 / 255-258$

Kasisa Shodhana [purification of Kasisa]

Purification of Kasisa was done according to Rasamitram-3/158 i.e. three times Bhawana of Bhringraj Swarasa [Eclipta Alba]. 
Table 1: Showing observations of Shodhana process

\begin{tabular}{|l|l|l|l|l|l|}
\hline Sample & $\begin{array}{l}\text { Weight of } \\
\text { Kasisa } \\
\text { (in gm) }\end{array}$ & $\begin{array}{l}\text { Number of } \\
\text { Bhavana }\end{array}$ & $\begin{array}{l}\text { Bhavana dravya } \\
\text { (Bhringaraja Swarasa) } \\
\text { Consumed (in ml) }\end{array}$ & $\begin{array}{l}\text { Weight of Kasisa } \\
\text { After Bhavana } \\
\text { (in gm) }\end{array}$ & $\begin{array}{l}\text { Weight loss of Kasisa after } \\
\text { Bhawana } \\
\text { (in \%) }\end{array}$ \\
\hline Sample 1 & $1500 \mathrm{gm}$ & 3 & $1950 \mathrm{ml}$. & $1350 \mathrm{gm}$ & $10 \%$ \\
\hline Sample 2 & $1500 \mathrm{gm}$ & 3 & $1950 \mathrm{ml}$. & $1350 \mathrm{gm}$ & $10 \%$ \\
\hline
\end{tabular}

\section{Kasisa Marana - Sample-1}

For Sample 1: 1350 gm of Shodhita Kasisa was taken and triturated for 3 hours with sufficient quantity of Nimbu Swarasa [as per definition of Bhawana] then pellet formation, drying of pellets was done and Puta was given. The process was repeated and 5 Putas were given.

Table 2: Showing observation of Marana [incineration] sample 1:

\begin{tabular}{|l|l|l|l|l|l|l|l|l|}
\hline Puta & $\begin{array}{l}\text { Sodhita } \\
\text { Kasisa } \\
\text { (in gm) }\end{array}$ & $\begin{array}{l}\text { Nimbu } \\
\text { Swaras } \\
\text { (ml) }\end{array}$ & $\begin{array}{l}\text { Wt. of } \\
\text { Chakrika af- } \\
\text { ter Bhavana } \\
\text { (gm) }\end{array}$ & $\begin{array}{l}\text { Wt. of } \\
\text { Cow dung } \\
\text { cakes } \\
\text { (gm/Puta }\end{array}$ & $\begin{array}{l}\text { Weight of } \\
\text { Chakrika } \\
\text { After } \\
\text { Puta }(\mathrm{gm})\end{array}$ & Colour & Hardness & $\begin{array}{l}\text { Wt. Loss of } \\
\text { Kasisa } \\
\text { Puta in } \%\end{array}$ \\
\hline 1 & $1350 \mathrm{Gm}$ & $700 \mathrm{ml}$ & $1430 \mathrm{gm}$ & $3500 \mathrm{gm}$ & $900 \mathrm{gm}$ & Yellowish green & Soft & $33.3 \%$ \\
\hline 2 & $900 \mathrm{gm}$ & $600 \mathrm{ml}$ & $960 \mathrm{gm}$ & $3000 \mathrm{gm}$ & $620 \mathrm{gm}$ & Blackish red & Very soft & $31.1 \%$ \\
\hline 3 & $620 \mathrm{gm}$ & $350 \mathrm{ml}$ & $650 \mathrm{gm}$ & $1500 \mathrm{gm}$ & $440 \mathrm{gm}$ & Blackish red & soft & $29 \%$ \\
\hline 4 & $440 \mathrm{gm}$ & $200 \mathrm{ml}$ & $398 \mathrm{gm}$ & $1000 \mathrm{gm}$ & $364 \mathrm{gm}$ & Red & Soft & $17 \%$ \\
\hline 5 & $364 \mathrm{gm}$ & $150 \mathrm{ml}$ & $371 \mathrm{gm}$ & $800 \mathrm{gm}$ & $350 \mathrm{gm}$ & Red & Soft & $3.8 \%$ \\
\hline
\end{tabular}




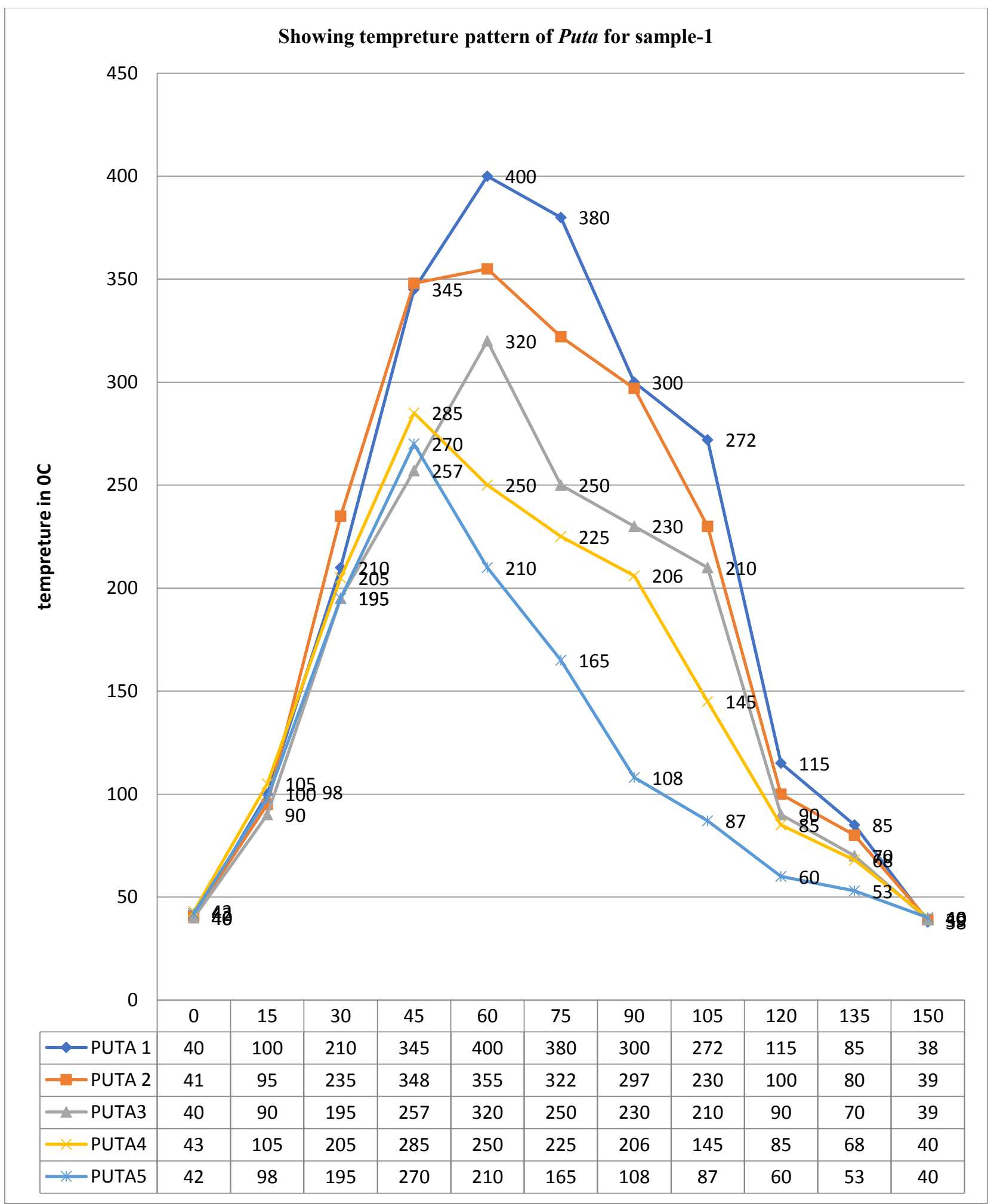




\section{Kasisa Marana - Sample-2}

For sample-2 1350 gm of Shodhita Kasisa was taken and triturated with Snuhipatra Swarasa for 3 hours and same process was done as shown in sample-1

Table 3: Showing observation of Marana (Incineration) Sample 2

\begin{tabular}{|l|l|l|l|l|l|l|l|l|}
\hline Puta & $\begin{array}{l}\text { Shodhit } \\
\text { Kasisa } \\
\text { (gm) }\end{array}$ & $\begin{array}{l}\text { Snuhi } \\
\text { Parta } \\
\text { Swarasa } \\
(\mathrm{ml})\end{array}$ & $\begin{array}{l}\text { Wt. of } \\
\text { Chakrika } \\
\text { After } \\
\text { Bhavna } \\
\text { (gm) }\end{array}$ & $\begin{array}{l}\text { Wt. of } \\
\text { Chakrika } \\
\text { After } \\
\text { Puta } \\
\text { (gm) }\end{array}$ & $\begin{array}{l}\text { Wt. of } \\
\text { Cow } \\
\text { dung } \\
\text { cakes in } \\
\text { gm/Puta }\end{array}$ & Colour & Hardness & $\begin{array}{l}\text { Wt. Loss } \\
\text { of Kasisa } \\
\text { after Puta }\end{array}$ \\
\hline 1 & $1350 \mathrm{gm}$ & $700 \mathrm{ml}$ & $1398 \mathrm{gm}$ & $840 \mathrm{gm}$ & $3500 \mathrm{gm}$ & Greenish yellow & Soft & $37 \%$ \\
\hline 2 & $840 \mathrm{gm}$ & $450 \mathrm{ml}$ & $895 \mathrm{gm}$ & $670 \mathrm{gm}$ & $3000 \mathrm{gm}$ & Blackish red & Soft & $20 \%$ \\
\hline 3 & $665 \mathrm{gm}$ & $350 \mathrm{ml}$ & $700 \mathrm{gm}$ & $560 \mathrm{gm}$ & $1500 \mathrm{gm}$ & Blackish red & Very soft & $15 \%$ \\
\hline 4 & $560 \mathrm{gm}$ & $250 \mathrm{ml}$ & $580 \mathrm{gm}$ & $540 \mathrm{gm}$ & $1200 \mathrm{gm}$ & Red & Very soft & $3 \%$ \\
\hline 5 & $540 \mathrm{gm}$ & $250 \mathrm{ml}$ & $570 \mathrm{gm}$ & $520 \mathrm{gm}$ & $1000 \mathrm{gm}$ & Red & Very soft & $3 \%$ \\
\hline
\end{tabular}




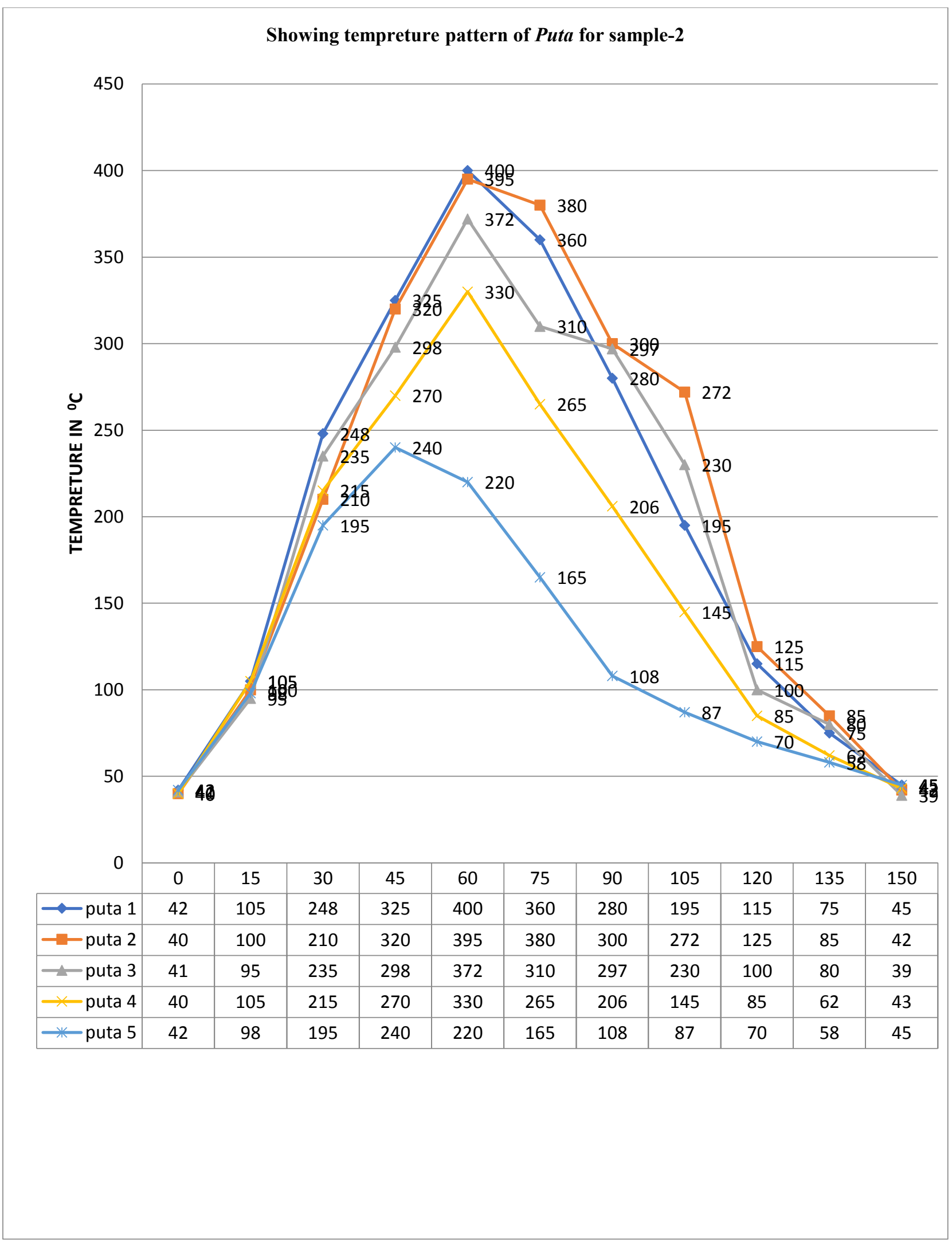


Analytical Study: The two samples of Kasisa Bhasma procured were subjected to organoleptic, classical Bhasma Pariksha parameters as well as physicochemical tests and total Iron percentage to analyse the products for the effect of different pharmaceutical procedures adapted in this study.

This analytical study was done in office of the Controller, Drugs testing laboratory Evam Anusandhana Kendra Raipur Chhattisgarh \& Chaukse laboratory limited Indore, M.P.

\section{Observations and Results:}

Observations of Pharmaceutical study-

Under pharmaceutical process for both samples initially $1350 \mathrm{gms}$ of Shodhita Kasisa was taken, and conventional Puta method was followed. Total 5 Puta were given to both samples. For sample-1 (Table No. 2) the incineration pattern shows marked reduction in weight after Puta, up to 4thPuta while the loss was 3.8\% after $5^{\text {th }}$ Puta finally $364 \mathrm{gms}$ of Kasisa Bhasma sample-1 was procured. For sample-2 (Table No. 3) incineration pattern shows maximum reduction in weight after $1^{\text {st }}$ Puta which gradually falls in $2^{\text {nd }}$ and $3^{\text {rd }} P u t a$, while there was least reduction in weight after $4^{\text {th }}$ and $5^{\text {th }}$ puta, and finally 540gms of Kasisa Bhasma was procured.

\section{Observations of Analytical study-}

Table 4: Showing Organoleptic characters of Kasisa Bhasma sample-1 and sample 2

\begin{tabular}{|l|l|l|l|}
\hline S. No. & Parameter & Sample 1 & Sample 2 \\
\hline $\mathbf{1 .}$ & Shabda & Absent & Absent \\
\hline $\mathbf{2 .}$ & Sparsha (Touch) & Smooth & Smooth \\
\hline $\mathbf{3 .}$ & Varna (Colour) & Red & Red \\
\hline $\mathbf{4 .}$ & Rasa (Taste) & Niramlatava $+\mathrm{ve}$ & Niramlatava $+\mathrm{ve}$ \\
\hline $\mathbf{5 .}$ & Gandha (Odour) & Odourless & Odourless \\
\hline $\mathbf{6 .}$ & Rekhapurnatva & Complies & Complies \\
\hline $\mathbf{7 .}$ & Slakshanatva & Complies & Complies \\
\hline $\mathbf{8 .}$ & Nishchandratva & Complies & Complies \\
\hline $\mathbf{9 .}$ & Laghuta & Complies & Complies \\
\hline $\mathbf{1 0}$ & Dantagrekachkachabhava & Complies & Complies \\
\hline
\end{tabular}

Table 5: Showing Physico-Chemical parameters of Kasisa-Impure, Kasisa-Sodhita Kasisa Bhasma sample-1 and sample-2

\begin{tabular}{|l|l|l|l|l|l|l|}
\hline S. No. & Sample name & $\begin{array}{l}\text { Loss on drying } \\
\% \mathrm{w} / \mathrm{w}\end{array}$ & $\begin{array}{l}\text { Ash value } \\
\% \mathrm{w} / \mathrm{w}\end{array}$ & $\begin{array}{l}\text { Acid soluble } \\
\text { Ash } \% \mathrm{w} / \mathrm{w}\end{array}$ & $\begin{array}{l}\text { Water soluble } \\
\text { ash } \% \mathrm{w} / \mathrm{w}\end{array}$ & $\begin{array}{l}\text { Total Iron } \\
\% \mathrm{w} / \mathrm{w}\end{array}$ \\
\hline 1 & Pushpa Kasisa(impure) & $37.15 \%$ & $58.03 \%$ & $0.13 \%$ & $47.13 \%$ & $26.45 \%$ \\
\hline 2 & Pushpa Kasisa (Shodhita) & $18.3 \%$ & $74.56 \%$ & $0.56 \%$ & $63.7 \%$ & $24.40 \%$ \\
\hline 3 & SAMPLE- 1 & $0.45 \%$ & $99.33 \%$ & $8.76 \%$ & $7.06 \%$ & $67.8 \%$ \\
\hline 4 & SAMPLE -2 & $0.25 \%$ & $99.6 \%$ & $7.7 \%$ & $6.1 \%$ & $59 \%$ \\
\hline
\end{tabular}

Analysis of organoleptic parameter shows that both samples complies the classical character of Bhasma. Both samples of Kasisa Bhasma were smooth, Slakshana, Rekhapurna, Laghu, Niramlatva and red in colour. Hence both the methods can be recommended to get Bhasma having classical standard characteristics. During incineration ferrous sulphate of raw Kasisa changes ferric and ferrous oxide which imparts red colour to the resultant Bhasma. Niramlatva test is an important parameter for Kasisa Bhasma Pariksha. $\mathrm{pH}$ of both sample was 4.8 and 5.7 respectively, which indicates Bhasma is acidic. But both samples comply $G a$ tarasatva (Niramlatva) test. 
Analysis of physicochemical parameters of both sample shows that both the samples complies loss on drying, loss on ignition, and ash value test. Acid insoluble ash value of sample-1 was $8.76 \%$ and sample-2 was $7.7 \%$, which favours the solubility of Bhasma in gastric media and hence it favours the therapeutic importance in terms of a physiological availability of the Bhasma. Total iron content of raw Kasisa was $26.45 \%$ w/w, while in sample-1 total iron was $67.8 \% \mathrm{w} / \mathrm{w}$ and in sample-2 total iron was $59 \% \mathrm{w} / \mathrm{w}$. It reflects that sample-1 contains more available iron hence therapeutically better than sample- 2 .

\section{CONCLUSION}

AFI recommends the text Rasamritam for Kasisa Marana, which was proven best on the recommended criteria. But on analysing the methods of Kasisa Marana in classical texts Snuhipatra Swarasa was specific than other advised Marana Dravyas, so comparative study was performed, and results were analysed. It is concluded that Snuhipatra Swarasaas Marana Dravyas can be recommended to get a classical standard Kasisa Bhasma. But therapeutically sample-1 that is Nimbu Swarasa Marita Kasisa Bhasma will be better for internal use, as the media used here, favours the gut absorption level. Classical review of Snuhi shows its indication in various compounds indicated for Kustha, Arsha, Shwitra, Bhagandar, Dadru etc. where mostly external use is recommended, As puta converts hard material into soft and fine organometallic form and also introduce new therapeutic properties through the herbs used, so here it can be concluded that Snuhipatra Swarasa Marita Kasisa Bhasma should be recommended for specially external use.

\section{REFERENCES}

1. The Ayurveda Formulary Of India, Part -1, Govt Of India, Ministry Of Health And Family Welfare, Department Of Ayush, Delhi, $2^{\text {nd }}$ Edition, Chapter 18/3 Page 600.

2. Rasamrita 3/159, Vaidya Yadavji Trikramji, Motilal Banarsi Das, Varanasi.

3. Rasa Tarangini By Pandit Sadanand Sharma, Shree Kashi Nath Shastri, Motilal Banarsidas, Delhi, Chapter 21/255-258
4. Sharangadhara Samhita- Shree Radha Krishna Parashr, Vaidyanath Ayurveda Bhavan, 4 ${ }^{\text {th }}$ edition 1994.

5. Bhavprakash Nighantu, Shree Brahama Shankara Shastri, Chaukambha Sanskrit Series Office Varanasi 1969.

6. Dravyaguna Vigyana, Acharya Priyavrata Sharma, Chaukhambha Bharti Prakashan, Chapter 2 Page No. 123

7. Dravyaguna Vigyana, Acharya Priyavrata Sharma, Chaukhambha Bharti Prakashan, Chapter 5, Page No.345 And 430.

\section{Source of Support: Nil \\ Conflict of Interest: None Declared}

How to cite this URL: Nirmala Kushwaha \& Urmila Waxar: A Comparative Pharmaceutico-Analytical Study Of Kasisa Bhasma Prepared By Two Methods W.S.R. To Marana Dravyas. International Ayurvedic Medical Journal \{online\} 2020 cited November, 2020\} Available from: http:/www.iamj.in/posts/images/upload/4969 4976.pdf 